\title{
Quantitative separation of radioactive sterols and bile acids in human faeces
}

\author{
B. LEWIS AND N.B. MYANT \\ From the Medical Research Council, Hammersmith Hospital, London
}

SYNOPSIS A method is described for the quantitative separation of radioactive bile acids and neutral sterols in human faeces on a potassium hydroxide-treated silicic acid column. Results obtained with faecal extracts containing metabolites derived from radioactive cholesterol, cholic acid, and chenodeoxycholic acid show that the efficiency of extraction is at least $96 \%$ and that mutual contamination between the bile-acid and sterol fractions is between 0.7 and $3.8 \%$. The method gives better results than one based on separation of the faecal steroids into saponifiable and unsaponifiable material.

The separate determination of faecal neutral sterols and bile acids is relevant to many problems concerning the regulation of cholesterol metabolism in man. In studies in which tracers were not used (Gordon, Lewis, Eales, and Brock, 1957; Antonis and Bersohn, 1962), saponification of faecal lipid has been employed to resolve neutral and acidic components. The bile-acid fraction separated in this way may be contaminated with sterols, as the present study has shown; although this would not interfere with titrimetric measurement, it would invalidate radio-assay. Another approach has been to use three-stage counter-current distribution between $70 \%$ ethanol and petroleum ether (Rosenfeld and Hellman, 1962).

Recently, Spritz and Ahrens (1963) have used 15-stage counter-current distribution followed by column and thin-layer chromatography to isolate bile-acid and sterol fractions of purity suited to titrimetric or gravimetric determination. Hellström and Sjövall (1962) employed a cation exchange column, anion exchange chromatography on DEAESephadex, and silicic acid chromatography, and then analysed bile acids by paper or gas chromatography. Bile acids have also been isolated on a Dowex $1 \times 2$ anion exchange column (Kuron and Tennent, 1961).

$3 \alpha, 7 \alpha, 12 \alpha$-Trihydroxycholanic acid (cholic acid) and $3 \alpha, 7 \alpha$-dihydroxycholanic acid (chenodeoxycholic acid), the chief bile acids synthesized by the human liver, are much more polar than cholesterol. However, both acids are converted by bacterial action in the caecum and colon into numerous Received for publication 14 February 1964. derivatives less polar than the parent acids, including deoxycholic, lithocholic (Rosenfeld and Hellman, 1962; Danielsson, Eneroth, Hellström, Lindstedt, and Sjövall, 1963), 3 $\beta, 12 \alpha$-dihydroxycholanic and isolithocholic acids (Danielsson et al., 1963), several ketocholanic acids (Danielsson et al., 1963), and possibly a less polar derivative of lithocholic acid (Bergström and Danielson, 1963). The presence of these derivatives of low polarity, together with mutual solubility effects in the complex lipid mixture extracted from faeces, may be responsible for the difficulty of separating bile acids from neutral sterols.

In developing the relatively simple method described in this paper, our aim was to obtain complete and quantitative separation of sterols and bile acids in a form suitable for radio-assay. We have tested the validity of the procedure in man by administering tritiated cholic and chenodeoxycholic acids and ${ }^{26-14} \mathrm{C}$ cholesterol, thus labelling the bile acids and sterols characteristic of human faeces. The method has been found satisfactory in the investigation of cholesterol metabolism in normal and hypercholesterolaemic subjects.

\section{MATERIALS AND METHODS}

REAGENTS All solvents were of analytical grade. Diethyl ether and dioxane were purified by passage through alumina columns; alumina (Peter Spence \& Sons Ltd., London) was activated at $120^{\circ} \mathrm{C}$. for 15 hours. Chloroform was washed five times with 0.2 vol. of water, dried over $\mathrm{CaCl}_{2}$, and distilled. The silicic acid was prepared as follows (Antonis, 1963): 100-mesh silicic acid (Mallinckrodt Chemical Works, New York City) was slurried five times with 10 vol. of distilled water, the coarse 
particles being allowed to settle each time for about three minutes before the fine particles were decanted. The coarse particles, representing about $50 \%$ of the starting material, were transferred to a Buchner funnel, washed with $10 \mathrm{vol}$. of acetone, and then with $5 \mathrm{vol}$. of ether which was removed as completely as possible.

This silicic acid was treated with potassium hydroxide. In a 1-litre round-bottomed flask, $50 \mathrm{~g}$. silicic acid was mixed with $200 \mathrm{ml}$. methanolic $\mathrm{KOH} 1 \cdot 25 \% \mathrm{w} / \mathrm{v}$, and the methanol removed in a rotary evaporator. Traces of methanol were displaced by washing the $\mathrm{KOH}$-treated silicic acid in a Buchner funnel with acetore and ether. The material may be used for at least two months if stored in a stoppered container.

THIN-LAYER CHROMATOGRAPHY Two systems were used. In one, the solid phase was Kieselgel H (E. Merck AG, Darmstadt, Germany) slurried with $0.05 \mathrm{~N}-\mathrm{NaOH}$ (15 g. $/ 45 \mathrm{ml}$.), and the moving phase was chloroform: methanol $(77 \cdot 5: 22.5 \mathrm{v} / \mathrm{v})$. The other system was that described by Eneroth (1963), in which the moving phase was diethyl oxalate: isopropanol $(48: 8 \mathrm{v} / \mathrm{v})$. Cholic acid (Hopkin \& Williams Ltd., Chadwell Heath, Essex), deoxycholic acid (L. Light \& Co. Ltd., Colnbrook, Bucks), lithocholic acid (Steraloids Ltd., Croydon, Surrey), and cholesterol (recrystallized, Hopkin \& Williams Ltd.) were used as markers.

RADIOACTIVE MATERIALS $4^{-14} \mathrm{C}$ Cholesterol, specific activity $54.5 \mu \mathrm{c} / \mathrm{mg}$., and $26-{ }^{14} \mathrm{C}$ cholesterol, specific activity $62.2 \mu \mathrm{c} / \mathrm{mg}$., were obtained from the Radiochemical Centre, Amersham, Bucks. The cholesterol was prepared for intravenous injection by adding it to a sample of the recipient's serum, essentially by the method of Whereat and Staple (1960). Cholic acid and chenodeoxycholic acid (Steraloids Ltd.) were uniformly labelled with tritium by a modification of the Wilzbach procedure, freed from labile tritium by washing an ether solution of the acids with water, and purified by thinlayer chromatography in the two solvent systems, with pure samples of cholic and chenodeoxycholic acids as markers. After elution from the thin-layer chromatograms with acetone, both bile acids gave single titration peaks on reversed-phase partition column chromatography (Sjövall, 1953).

PROCEDURE A four-day collection of faeces is homogenized with $\frac{1}{2}$ to $1 \times$ its weight of water; an aliquot of 10 to $20 \mathrm{~g}$. is weighed in a $250-\mathrm{ml}$. flask and extracted under reflux with $150 \mathrm{ml}$. acetone for four hours in a water-bath at $90^{\circ} \mathrm{C}$. The solvent is filtered and the extraction repeated once with acetone and twice with $150 \mathrm{ml}$. chloroform. Fifteen g. of Dowex $50 \mathrm{~W}-\mathrm{X} 2$, 50-100 mesh (Bio-Rad Laboratories, Richmond, California) is slurried in glass-distilled water and packed in a column of $1.2 \mathrm{~cm}$. internal diameter. It is washed with $50 \mathrm{ml}$. $\mathrm{N}-\mathrm{HCl}$ and then with distilled water until the effluent is neutral. The column is then washed with $50 \mathrm{ml}$. acetone : chloroform: water $(50: 50: 1 \mathrm{v} / \mathrm{v})$. The pooled extract is then passed through the column, on which part of the pigment is retained; the column is washed through with $20 \mathrm{ml}$. chloroform: acetone: water (50:50:1), and the whole eluate taken to dryness in a rotary evaporator. Two tenths of the eluate is saponified under reflux with $5 \mathrm{ml}$. N-NaOH in $80 \% \mathrm{v} / \mathrm{v}$ aqueous dioxanes in a boiling water-bath; after 30 minutes, a further $5 \mathrm{mto}$ water is added, and saponification continued for $9 F_{5}$ minutes. The cooled solution is acidified to $p \mathrm{H} 1$ witle $\mathrm{N}-\mathrm{HCl}$ and extracted three times with 2 vol. of ether? The pooled ether extract is taken to dryness in a rotary evaporator, complete removal of water being ensured by adding $5 \mathrm{ml}$. acetone to the residue and re-evaporating. $\vec{\circ}$

For chromatography, $3 \mathrm{~g}$. silicic acid- $\mathrm{KOH}$, slurried in ether and packed in a column $8 \mathrm{~mm}$. in diameter, is washed with $20 \mathrm{ml}$. acetone, then $20 \mathrm{ml}$. ether, and finally $20 \mathrm{ml} .70 \% \mathrm{v} / \mathrm{v}$ ether in hexane. The saponifie faecal lipid is dissolved in $1 \mathrm{ml}$. chloroform, and $0.5 \mathrm{ml}:$ is pipetted on to the column. Neutral sterols are elute with $120 \mathrm{ml} .70 \%$ ether in hexane, and bile acids with $100 \mathrm{ml} .4 \%$ formic acid in methanol v/v. The evaporate $b$ residue of the second fraction is dissolved in $100 \mathrm{ml}$. chloroform and washed twice with $5 \mathrm{ml}$. $0.02 \mathrm{~N}-\mathrm{HCl}$ The chloroform is then taken to dryness.

The sterol and bile-acid residues are taken up in $4 \mathrm{mk}$ ethanol, and $2 \mathrm{ml}$. is transferred to counting vials fo radio-assay in a Packard Tri-Carb liquid scintillatio spectrometer, with $10 \mathrm{ml}$. toluene containing $0.4 \%$ diphenyloxazole and 0.01\% 1,4-bis-(2-(5-phenyl-oxazolyleb benzene. Internal standards of ${ }^{4-14} \mathrm{C}$ cholesterol of U- ${ }^{3} \mathrm{~T}$ chenodeoxycholic acid, containing about 50,000 c.p.m., are used to correct for quenching.

\section{RESULTS}

RECOVERY OF LABELLED BILE ACIDS AND STEROL FROM FAECES The recovery of endogenous bil acids and sterols from faeces cannot be estimate $\Phi$ satisfactorily by measuring the recovery of radios active bile acids and sterols added to faeces in vitrop. because endogenous steroids may be bound to insoluble residues in faeces. It has recently beêิ shown, for instance, that lithocholic acid in a faecaf suspension, unlike deoxycholic acid, sediments $\overline{i \bar{B}}$ the ultracentrifuge and may be intrabacteria (Norman and Shorb, 1962). In order to estimate the losses which occur during the extraction, we have therefore used faeces obtained from hospital in patients, four to $\mathbf{3 0}$ days after intravenous injectio of $4^{-14} \mathrm{C}$ cholesterol, $80 \mu \mathrm{c}$, or after oral administras tion of $26-{ }^{14} \mathrm{C}$ cholesterol, $15 \mu \mathrm{c}$ dissolved in olive oil. In the former, the endogenous neutral steros and bile acids were labelled; in the latter, the ${ }^{14} \mathbb{C}$ was almost entirely in the neutral sterols; bile acid were not labelled because of oxidative removal of the radioactive carbon atom. Losses in the initiall extraction and in the subsequent analysis of the faecal extract were measured separately.

For estimation of the efficiency of the initiol extraction, the faeces were extracted with acetone and chloroform by the standard procedure and the radioactivity in the extract measured. The faecd 
residue was then digested in $5-\mathrm{N}$ aqueous $\mathrm{NaOH}$ at $100^{\circ} \mathrm{C}$. for five hours, acidified, and extracted three times with chloroform. The activity in the pooled chloroform extracts were measured using an internal standard to correct for quenching due to pigment. An average of $0.4 \%$ of the total activity remained in the residue after the initial extraction (Table I).

\section{TABLE I}

RECOVERY OF RADIOACTIVE ENDOGENOUS STEROIDS BY ACETONE/CHLOROFORM EXTRACTION OF FAECES

\begin{tabular}{|c|c|c|c|}
\hline \multirow[t]{2}{*}{ Sterol Administered } & \multicolumn{2}{|c|}{ Activity (d.p.m.) } & \multirow{2}{*}{$\begin{array}{l}\text { Percentage of } \\
\text { Total Recovered } \\
\text { in Acetonel } \\
\text { Chloroform }\end{array}$} \\
\hline & Residue & $\begin{array}{l}\text { Acetonel } \\
\text { Chloroform }\end{array}$ & \\
\hline 4-14 $\mathrm{C}$ cholesterol & 0 & 68,984 & $100 \cdot 0$ \\
\hline${ }^{4-14} \mathrm{C}$ cholesterol & $\mathbf{0}$ & 43,843 & $100 \cdot 0$ \\
\hline${ }^{4-14} \mathrm{C}$ cholesterol & 30 & 30,230 & 99.9 \\
\hline${ }^{4-14} \mathrm{C}$ cholesterol & 55 & 15,790 & $99 \cdot 6$ \\
\hline 4-14 $\mathrm{C}$ cholesterol & 303 & 31,030 & 99.0 \\
\hline${ }^{4-14} \mathrm{C}$ cholesterol & 0 & 21,998 & $100 \cdot 0$ \\
\hline${ }^{4-14} \mathrm{C}$ cholesterol & 248 & 21,042 & $98 \cdot 8$ \\
\hline \multirow[t]{2}{*}{$26-{ }^{14} \mathrm{C}$ cholesterol } & 215 & 99,167 & $99 \cdot 8$ \\
\hline & & Mean: & $99 \cdot 6$ \\
\hline
\end{tabular}

Losses during the remainder of the procedure were estimated from the radioactivity recovered when samples of initial extracts, containing known amounts of activity, were submitted to the whole analytical procedure. The average loss in five experiments was $3.5 \%$ (Table II).

\section{TABLE II}

RECOVERY OF RADIOACTIVE ENDOGENOUS STEROIDS AFTER CHROMATOGRAPHY ON DOWEX AND SILICIC ACID COLUMNS

\begin{tabular}{|c|c|c|c|}
\hline \multirow[t]{2}{*}{ Sterol Administered } & \multicolumn{2}{|c|}{ Activity (d.p.m.) } & \multirow{2}{*}{$\begin{array}{l}\text { Percentage } \\
\text { Recovered }\end{array}$} \\
\hline & $\begin{array}{l}\text { Faecal } \\
\text { Extract }\end{array}$ & $\begin{array}{l}\text { Sterol Plus } \\
\text { Bile Acid } \\
\text { Fractions }\end{array}$ & \\
\hline $\begin{array}{l}4-{ }^{14} \mathrm{C} \text { cholesterol } \\
4^{11} \mathrm{C} \text { cholesterol } \\
4^{14} \mathrm{C} \text { cholesterol } \\
4-{ }^{14} \mathrm{C} \text { cholesterol }\end{array}$ & $\begin{array}{r}68,350 \\
131,170 \\
57,360 \\
16,440\end{array}$ & $\begin{array}{r}67,920 \\
122,290 \\
58,226 \\
14,520\end{array}$ & $\begin{array}{r}99 \cdot 4 \\
93 \cdot 2 \\
101 \cdot 5 \\
88 \cdot 3\end{array}$ \\
\hline $26-{ }^{14} \mathrm{C}$ cholesterol & 15,070 & $\begin{array}{l}15,068 \\
\text { Mean: }\end{array}$ & $\begin{array}{r}100 \cdot 0 \\
96 \cdot 5\end{array}$ \\
\hline
\end{tabular}

SEPARATION OF BILE ACIDS AND STEROLS The efficiency with which bile acids and neutral sterols are separated by this procedure was tested by analysing faeces obtained from six hospital inpatients, all without evidence of disease of the gastro-intestinal or biliary tract, given radioactive bile acids or cholesterol by mouth. Three of these patients had ${ }^{3} \mathrm{H}$ cholic acid $(60 \mu \mathrm{c})$, two had ${ }^{3} \mathrm{H}$ chenodeoxycholic acid $(60 \mu \mathrm{c})$ and one had $26-{ }^{14} \mathrm{C}$ cholesterol $(15 \mu \mathrm{c})$. Faeces were collected on the fourth to sixth days and analysed as described above. Our data therefore represent recoveries on the one hand of the metabolites of the main bile acids formed by the human liver, and, on the other, of cholesterol and its $\mathrm{C}_{27}$ metabolites.

Table III shows the amount of activity in the non-polar and polar fractions of the faecal extracts from each of the six patients. Metabolites of cholic and chenodeoxycholic acids are eluted almost entirely in the polar fraction, contamination of the non-polar fraction being slightly greater with derivatives of chenodeoxycholic acid $(2 \cdot 36 \%)$ than with those of cholic acid (1.2\%). Cholesterol and its $\mathrm{C}_{27}$ metabolites are eluted almost entirely in the non-polar fraction, $2.05 \%$ appearing in the polar fraction.

\section{TABLE III}

RADIOACTIVITY IN COLUMN ELUATES FROM FAECAL EXTRACTS OBTAINED FROM PATIENTS GIVEN LABELLED STEROIDS

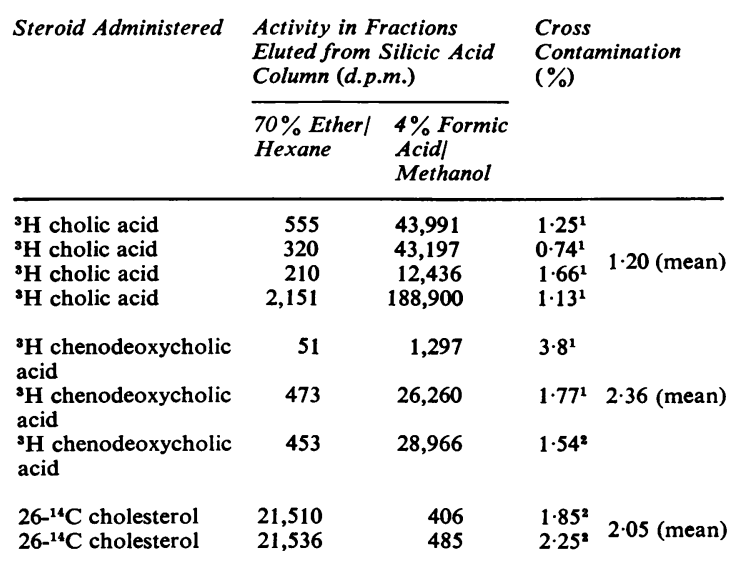

${ }^{1}$ Percentage of total count in sterol fraction ${ }^{2}$ Percentage of total count in bile acid fraction

THIN-LAYER CHROMATOGRAPHY OF THE BILE-ACID AND STEROL FRACTIONS In an attempt to characterize the main radioactive components of the two eluates from the silicic acid column, aliquots from the polar and non-polar fractions were analysed by thin-layer chromatography with the chloroform: methanol solvent system. After completion of the chromatography, 15-mm. bands of the dried silicic acid were scraped off the plates, eluted with ethanol and the radioactivity in the eluates assayed.

Figure 1 shows the distribution of activity in chromatograms from the faecal extracts obtained from three patients. In the polar fraction from the patient given ${ }^{3} \mathrm{H}$ cholic acid, most of the radioactivity was separated into two peaks, one close to the position of the deoxycholic acid marker and the other close to that of lithocholic acid; smaller amounts of activity were also present near the solvent front. Similarly, in the polar fraction from 

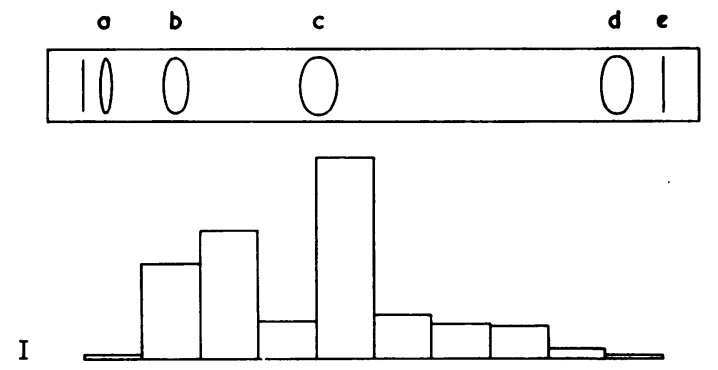

II

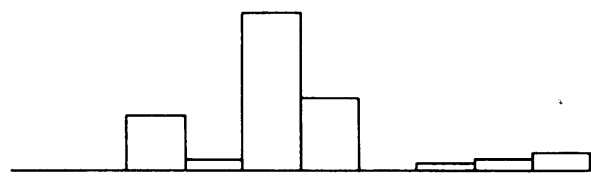

III

FIG. 1. Thin-layer chromatography of faecal lipid, showing distribution of radioactivity. The solvent was chloroform : methanol $(77.5: 22.5 v / v)$, and Kieselgel $H$ was used, slurried with 0.05 N-NaOH. I Polar fraction from subject given ${ }^{3} \mathrm{H}$ cholic acid. II Polar fraction from subject given ${ }^{3} \mathrm{H}$ chenodeoxycholic acid. III Non-polar fraction from subject given $26-{ }^{4} C$ cholesterol. a, cholic acid; b, deoxycholic acid; c, lithocholic acid; $\mathrm{d}$, cholesterol; $\mathrm{e}$, solvent front.

the patient given ${ }^{3} \mathrm{H}$ chenodeoxycholic acid, most of the activity was in two peaks, the smaller running slightly faster than deoxycholic acid and the larger corresponding to that of the lithocholic acid marker; a small amount of fast-running activity was again detected. In the non-polar fraction from the faeces of the patient given ${ }^{26-{ }^{14} \mathrm{C}}$ cholesterol, all the activity moved to a position corresponding to that of cholesterol or of material less polar than cholesterol.

SEPARATION OF BILE ACIDS AND STEROLS BY SAPONIFICATION The method was compared with one based on the separation of faecal lipids into saponifiable and unsaponifiable fractions, using the faecal extracts obtained from patients given ${ }^{3} \mathrm{H}$ cholic acid, ${ }^{3} \mathrm{H}$ chenodeoxycholic acid, and ${ }^{26-{ }^{14}} \mathrm{C}$ cholesterol (Table III). Aliquots of the lipid extract were saponified with $\mathrm{N}-\mathrm{NaOH}$ in $80 \%$ ethanol under reflux at $90^{\circ} \mathrm{C}$. for four hours. An equal volume of water was added and the unsaponifiable material extracted three times with 2 vol. hexane. The aqueous residue was acidified to $p \mathrm{H} 4$ by adding $\mathrm{N}-\mathrm{HCl}$ and extracted three times with 2 vol. ether.
The radioactivity in the unsaponifiable and saponifie able fractions from the faeces of the three patients is shown in Table IV. The saponifiable fractio contained $14.5 \%$ of cholesterol and its $\mathrm{C}_{27}$ derive atives, though contamination of the unsaponifiable fraction with bile-acid metabolites was not extensiven

TABLE IV

RADIOACTIVITY IN SAPONIFIABLE AND UNSAPONIFIABL $\vec{\oplus}$ FRACTIONS FROM FAECAL EXTRACTS OBTAINED FROM. PATIENTS GIVEN LABELLED STEROIDS

$\begin{array}{lll}\text { Steroid Given } & \text { Activity (d.p.m.) } & \begin{array}{l}\text { Cross } \\ \text { Contamination } \\ \begin{array}{l}\text { Unsaponi- } \\ \text { fiable }\end{array}\end{array} \text { Saponifiable }(\%)\end{array}$

\begin{tabular}{lllll}
\hline${ }^{3} \mathrm{H}$ cholic acid & 327 & 17,105 & $1 \cdot 9^{1}$ & O \\
${ }^{3} \mathrm{H}$ cholic acid & 219 & 13,751 & $1 \cdot 6^{1}$ &
\end{tabular}



${ }^{2}$ Percentage of total count in saponifiable fraction.

\section{DISCUSSION}

Loss of endogenous faecal steroids during the whole procedure, including extraction of the faeces and chromatographic separation of the extract, is on the average $4 \%$ (Tables I and II); this is probably reflection of the relative simplicity of the methods Separation of bile-acid metabolites from neutrat sterols is sufficiently complete for the purpose fo which this method was designed, though 0.7 to $3.8 \%$ mutual contamination (Table III) might not be acceptable for other purposes. The efficiency of separation is much better than that of a methot based simply on separation into saponifiable an unsaponifiable material, in which more than $10 \%$ of sterols may contaminate the saponifiable materia田 (Table IV).

In the experiments to test the extent of contamin ation of one fraction by another, the faecal sterolss were labelled by giving the patient $26^{-14} \mathrm{C}$ cholestero? Although no radioactivity would appear in the $\mathrm{C}_{24}$ bile acids, it is possible that $\mathrm{C}_{27}$ acids may be excreted in the faeces. It has been shown, fog example, that radioactive trihydroxycoprostanic acio was excreted in the bile of a human subject given 26- ${ }^{14} \mathrm{C}$ cholesterol intravenously (Staple and Rabino ${ }^{\text {? }}$ witz, 1962). Traces of this substance, or of othero $\mathrm{C}_{27}$ acids, could explain the observation that $2 \%$ o the radioactivity in the faecal extract of the patien $\$$ given ${ }^{26-14} \mathrm{C}$ cholesterol was present in the polag fraction (Table III). 
Thin-layer chromatography of the polar fractions from patients given radioactive bile acids shows that cholic and chenodeoxycholic acids are to some extent converted to metabolites of low polarity (Fig. 1). This is in agreement with the detailed observations of Danielsson et al. (1963), and such metabolites may account for the radioactivity in the non-polar fractions from patients given labelled bile acids (Table III).

It may be noted that ethanol is not used until the final stages of the procedure. It seemed possible that esterification of bile acids might otherwise occur, resulting in contamination of the neutral sterol fraction with bile-acid esters.

\section{REFERENCES}

Antonis, A. (1963). Personal communication.

- , and Bersohn, I. (1962). Amer. J. clin. Nutr., 11, 142.

Bergström, S., and Danielsson, H. (1963). Biochem. Soc. Symp., 24, 63.

Danielsson, H., Eneroth, P., Hellström, K., Lindstedt, S., and Sjövall, J. (1963). J. biol. Chem., 238, 2299.

Eneroth, P. (1963). J. Lipid Res., 4, 11.

Gordon, H., Lewis, B., Eales, L., and Brock, J. F. (1957). Lancet, 2, 1299.

Hellström, K., and Sjövall, J. (1962). J. Lipid Res., 3, 397.

Kuron, G. W., and Tennent, D. M. (1961). Fed. Proc., 20(1), 268.

Norman, A., and Shorb, M. S. (1962). Proc. Soc. exp. Biol. (N.Y.), $110,552$.

Rosenfeld, R. S., and Hellman, L. (1962). Arch. Biochem., 97, 406.

Sjövall, J. (1953). Acta physiol. scand., 29, 232.

Spritz, N., and Ahrens, E. H. Jr. (1963). In Biochemical Problems of Lipids, edited by A. C. Frazer, p. 66. Elsevier, Amsterdam.

Staple, E., and Rabinowitz, J. L. (1962). Biochim. biophys. Acta (Amst.), 59, 735.

Whereat, A. F., and Staple, E. (1960). Arch. Biochem., 90, 224.

\section{Broadsheets prepared by the Association of Clinical Pathologists}

The following broadsheets (new series) are published by the Association of Clinical Pathologists. They may be obtained from Dr. R. B. H. Tierney, Pathological Laboratory, Boutport Street, Barnstaple, N. Devon. The prices include postage, but airmail will be charged extra.

3 The Detection of Barbiturates in Blood, Cerebrospinal Fluid, Urine, and Stomach Contents. 1953. L. C. NICKOLLS. 1s.

4 The Estimation of Carbon Monoxide in Blood. 1953. D. A. STANLEY. 1s.

13 The Identification of Serotypes of Escherichia coli Associated with Infantile Gastro-enteritis. 1956. JOAN TAYLOR. $1 \mathrm{~s}$.

16 Preservation of Pathological Museum Specimens. 1957. L. W. PROGER. 1s.

17 Cultural Diagnosis of Whooping-cough. 1957. B. W. LACEY. $1 \mathrm{~s}$.

20 Investigation of Porphyrin/Porphyria. 1958 (reprinted 1962). C. RIMINGTON. 2s.

23 The Dried Disc Technique for Bacterial Sensitivity Tests. 1959. R. W. FAIRBROTHER and J. C. SHERRIS. 1s.

24 Safe Handling of Radioactive Tissues in the Laboratory and Post-mortem Room. 1959. R. C. CURRAN. $1 \mathrm{~s}$.

26 The Periodic Acid-Schiff Reaction. 1959. A. G. E. PEARSE. 1s.

28 Daily Fatty Acid Excretion. 1960. A. C. FRAZER. 2s.

29 The Preparation of Bone for Diagnostic Histology. 1960. D. H. COllins. 2s.

30 Control of Accuracy in Chemical Pathology. 1961. G. H. GRANT. $4 s$.

31 Investigation of Haemorrhagic States with Special Reference to Defects of Coagulation of the Blood. 1961. E. K. BLACKBURN. 4s.

32 Detection of Resistance to Streptomycin, P.A.S., and Isoniazid in Tubercle Bacilli. 1961. R. CRUICKSHANK and s. M. STEWART. $2 s$.
33 The Laboratory Detection of Abnormal Haemoglobins. 1961. H. LEHMANN and J. A. M. AGER. 4s.

34 Titration of Antistreptolysin O. 1961. H. GOODER and R. E. O. WILLIAMS. 2s.

35 The Estimation of Faecal 'Urobilinogen'. 1961. C. H. GRAY. $2 s$.

36 Quantitative Determination of Porphobilinogen and Porphyrins in Urine and Faeces. 1961. C. RIMINGTON. 3s. $6 \mathrm{~d}$.

37 The Paper Electrophoresis of Serum and Urinary Proteins. 1961. G. FRANGLEN and N. H. MARTIN. 4S.

38 The Augmented Histamine Gastric Function Test. 1961. M. LUBRAN. 2s.

39 Investigation of Haemolytic Anaemia. 1961. J. G. SELWYN. $2 \mathrm{~s}$.

40 Short-term Preservation of Bacterial Cultures. 1962. E. JOAN STOKES. 2s.

41 Serological Tests for Syphilis. 1962. A. E. WILKINson. 6s.

42 The Determination of Glucose 6-Phosphate Dehydrogenase in Red Cells. 1962. T. A. J. PRANKERD. 2s.

43 Mycological Techniques. 1962. R. W. RIDDELL. 3s. 6d.

44 The Laboratory Investigation of Catecholamine Secreting Tumours. 1963. M. SANDLER and C. R. J. RUTHVEN. $2 \mathrm{~s}$.

45 Diagnostic Test for Hereditary Galactosaemia. 1963. v. SCHWARZ. 2 s.

46 The Determination of Serum Iron and Total Iron Binding Capacity. 1963. A. JORDAN and D. A. PODMORE. 2s.

47 Nuclear Sexing. 1964. B. LENNOX and W. M. DAVIDSON. 2 s. 